\title{
A comparative evaluation between the impact of previous outbreaks and COVID-19 on the tourism industry
}

\author{
Gulcin Ozbay, Mehmet Sariisik and Veli Ceylan \\ Gastronomy and Culinary Arts, Sakarya University of Applied Sciences, \\ Sakarya, Turkey, and \\ Muzaffer Çakmak \\ Gastronomy and Culinary Arts, İstanbul Gelişim University, Istanbul, Turkey
}

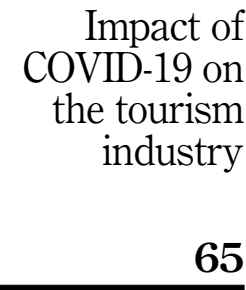

Received 11 November 2020 Revised 9 January 2021 Accepted 10 January 2021

\begin{abstract}
Purpose - The main purpose of this study is to make a comparative evaluation of the impacts of previous outbreaks and coronavirus disease 2019 (COVID-19) on the tourism industry. COVID-19 appears to have disrupted all memorizations about epidemics ever seen. Nobody has anticipated that the outbreak in late December will spread rapidly across the world, be fatal and turn the world economy upside down. Severe acute respiratory syndrome, Ebola, Middle East respiratory syndrome and others caused limited losses in a limited geography, thus similar behaviors were expected at first in COVID-19. But it was not so. Today, people continue to lose their lives and experience economic difficulties. One of the most important distressed industries is undoubtedly tourism.

Design/methodology/approach - This study is a literature review. In this review, a comparative evaluation between the impact of previous outbreaks and COVID-19 on the tourism industry has been made based on statistics and previous research studies.

Findings - The information and figures obtained show that COVID-19 and previous outbreaks have such significant differences that cannot be compared. COVID-19 has been one of the worst to live in terms of spreading speed, the geography where it spreads, loss of lives and negative effects in the whole area.

Originality/value - It is noteworthy that COVID-19 is very severe in terms of death cases and also its impacts on the economy compared to other pandemics. It remains to be argued that COVID-19 can also be a reference in terms of possible new outbreaks in the future, and is an effective actor in determining future strategies.
\end{abstract}

Keywords COVID-19, Pandemic, Outbreaks, COVID-19's impacts, Tourism

Paper type Literature review

\section{Introduction}

Epidemic diseases that have been experienced at different periods and in different levels of violence, especially in the 20th $(1918,1957,1968)$ and 21st century $(2003,2009,2012,2015)$, cause significant changes in human and social life (Mills et al., 2004; WHO, 2020a). It is stated that the number of "influenza A" outbreaks have been 10 in the last 300 years (Osterholm, 2005). Coronavirus disease 2019 (COVID-19) is the third serious outbreak caused by a coronavirus (Wang et al., 2020a). Flu outbreaks are always described as a major global infectious disease threat (Osterholm, 2005), spreading rapidly and causing deaths of millions of people worldwide (Mills et al., 2004). Outbreaks with a lethal force cause many socioeconomic problems such as serious economic stagnation, social and political turmoil,

(C) Gulcin Ozbay, Mehmet Sariisik, Veli Ceylan and Muzaffer Çakmak. Published in International Hospitality Review. Published by Emerald Publishing Limited. This article is published under the Creative Commons Attribution (CC BY 4.0) licence. Anyone may reproduce, distribute, translate and create derivative works of this article (for both commercial and non-commercial purposes), subject to full attribution to the original publication and authors. The full terms of this licence may be seen at http:// creativecommons.org/licences/by/4.0/legalcode

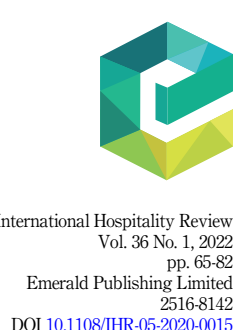

DOI 10.1108/IHR-05-2020-0015 
IHR

36,1

\section{6}

unemployment, poverty, food insecurity in addition to the direct impact as the loss of life (Yeganeh, 2019). Developing strategies such as case isolation, home quarantine, closure of schools and workplaces, travel restrictions to alleviate the severity of a new outbreak are considered as the global public health priority (Ferguson et al., 2006; Yeganeh, 2019). Mills et al. (2004) warned that if a pandemic similar to 1918 is experienced, the number of cases will increase rapidly due to increased travel, and subsequent deaths will double approximately every three days. Jayawardena et al. (2008) emphasize that the key point is planning, and previous outbreaks are important in this regard.

Pandemics cause a great deal of economic damage and loss of life. There are even explanations that the number of potential deaths is more effective than a nuclear bomb (Nigmatulina and Larson, 2009). Osterholm (2005) points out that loss of life will be devastating even in a mild pandemic, and that the world economy will have to bear several years of turmoil costs. The economies of countries not affected by the epidemic also suffer due to the fear of the disease (Yeganeh, 2019). It is known that the economic cost of infectious epidemics is greater than the sum of direct health effects. Outbreaks have an economic impact on macro and micro dimensions with production factors in various sectors (Keogh-Brown, 2014). An epidemic also has indirect costs, and these costs arise from the possibility of the public becoming ill and the risks posed by the epidemic (Smith, 2006). Pandemics do not affect all people in the same way. Especially people in the low-income group suffer more. The "Black Death" in the 14th century has reduced the global population by one-third, and death cases had been seen the greatest in poor people (Ahmed et al., 2020). This is also valid for countries. Compared to high-income economies, the effects of outbreaks on the national economy, security, health insurance policy, legal frameworks and investment flows are felt more in low-and middle-income countries (de Francisco et al., 2015).

The tourism industry is more affected by epidemics because of travel restrictions imposed by governments cause reductions in both domestic and international travel. Therefore, the travel and accommodation sectors are described as the sectors that were first damaged in an outbreak (Bharwani and Mathews, 2012; Menon and Goh, 2005). Tourism revenues and the share of tourism in gross national product decrease due to outbreaks (Pine and McKercher, 2004; Jayawardena, 2008; Keogh-Brown and Smith, 2008; Bhati et al., 2016). Tourism enterprises and destinations, which are vulnerable to epidemic diseases, should prepare and implement integrated strategic plans (Bhati et al., 2016; Cahyanto et al., 2016; Jayawardena, 2008).

Studies examining the effects of epidemic diseases in the tourism industry can be listed as follows: Jamal and Budke (2020), Hoque et al. (2020), Dinarto et al. (2020), Acar (2020), Kim et al. (2020), Yang et al. (2020), Lock (2020), Haque and Haque (2018), Bhati et al. (2016), Cahyanto et al. (2016), Sifolo and Sifolo (2015), Ketshabile (2013), Bharwani and Mathews (2012), Zengeni and Zengeni (2012), Lee and Chen (2011), Min et al. (2011), Avc1kurt et al. (2011), McAleer et al. (2010), Wu et al. (2010), Yanni et al. (2010), Tufts (2009), El-Sayyed et al. (2008), Kuo et al. (2008), Henderson and Linh (2007), Chuo (2007), Lee and Warner (2006), Page et al. (2006), Yeoman et al. (2006), Page et al. (2006), Wall (2006), Luo and Tan (2005), Kim et al. (2005), Zeng et al. (2005), Valette et al. (2004), Pine and McKercher (2004), Breda (2004) and McKercher (2003).

Epidemic diseases frequently experienced in history of humanity both caused significant loss of lives and have many psychological, economic and sociological effects. It is accepted that each new outbreak will serve as a reference in terms of the pandemic that will come next. In order to make inferences about the effects of COVID-19 on the tourism industry, the situations that occurred in previous outbreaks should be analyzed. The main purpose of this research is to explain the effects of COVID-19 and previous epidemics on the tourism economy. For this, a comparative evaluation will be made in terms of the impact and mortality rates of epidemic diseases, and the effects on economic structure 
and unemployment. In the first section of the study, previous epidemics were examined, and their economic effects were presented. In the next section, COVID-19 and its economic effects are emphasized, and finally, the damages of epidemic diseases to society and economy are evaluated comparatively.
Impact of
COVID-19 on

the tourism industry

\section{Pandemics in the past and their effects on tourism}

Microorganisms having a history of millions of years have caused many negative and positive events through historical process. While various organisms and mainly bacteria, prepare ground for beneficial works such as converting animal and plant residues into micronutrients, converting consumed foods into digestible nutrients, fermenting cheese and wine (Gilliland, 1990), they have also caused for many diseases treatment of which is difficult, at the same time. As with the settled lifestyle hunting and collections were replaced by agriculture, this has caused for people to be more interacted with soil, animals and plants. As a result of this situation, passage of microorganisms from existing soil, animals and plants to humans have pioneered for various diseases to come out. Barberry disease coming out with domestication of the dog, diphtheria and tuberculosis coming out with soil domestication of anthrax, are only a few of the outcomes emerging as a result of this interaction. Furthermore, as forests and natural living areas are destroyed and transformed into settlement areas as being parallel to the increase in population, it was caused for creatures such as mice, lice, fleas and ticks being present in these areas to get in contact with humans. As a result of this, biggest epidemic of history such as plague has emerged (Nikiforuk, 2018, pp. 19-28).

\section{Flu outbreaks (Spanish, Asian, Hong Kong, swine)}

Spanish flu, having high spread rate (it has taken this name as it has spread from Spain to France (Porras-Gallo and Davis, 2014), is one of the epidemic diseases, which has caused most number of death incidents in the near past. Although there are variations as per research outcomes, it is predicted that the disease was spreaded to nearly 500 million people, and it has caused the death of more than 50 million people (Rosenwald, 2020). As a big increase has occurred in tourism activities following Second World War, the impact of this disease on other sectors rather than tourism has also been among the research topics. Spanish flu has caused for daily life and economy to come to the point of stopping in many countries. In his study, Ammon (2002) has stated that due to this disease, many schools were closed in Geneva, and also meetings and all events (sports, theaters, etc.) have been restricted. Karlsson et al. (2014) have stated that Spanish flu have caused for economical life to come to the point of stopping in Sweden. In this study, it is stated that due to the disease, incomes have reduced and that poverty rates have increased. In a study conducted by Garrett (2007) in the USA, it has been mentioned that this disease has caused for many enterprises to shutdown in the USA and for the operating enterprises to have works being reduced as per the rates of $40-70 \%$. It is underlined that the daily loss of enterprises is around the values of $10,000-15,000 \$$.

Flu outbreak which has occurred on the date being closest to our time has been swine flu. The virus which came out in Mexico in 2009 has caused for the loss of more than 200.000 people (Moran and Del Valle, 2016, p. 2). The pandemic, which has also affected tourism sector negatively, has caused for cancelation of holiday and airway reservations on a large scale (McKibbin, 2009). Swine flu outbreak has affected tourism activities of many countries negatively. Page et al. (2011), have stated that due to swine flu loss of 1.6 million tourists was experienced in England in 2009. Furthermore, it was mentioned in this study that swine flu outbreak has caused for a revenue loss of 940 million sterling. In the study they carried out in Brunei by Haque and Haque (2018), it was mentioned that swine flu outbreak has caused for 
IHR

36,1

68

the loss of nearly 30,000 tourists and revenue loss of $\$ 15$ million in this country. When it is considered that Brunei is a small country, the mentioned losses reflect that the outbreak has caused a significant impact in this country. Among the countries being negatively affected with respect to tourism activities, Mexico where the pandemic has come out, ranks at the forefront. Garg (2013) mentioned that due to swine flu outbreak, many touristic organizations have been canceled, and that tourism enterprises have been shutdown. Besides, the leading global traveling agencies have canceled all of their reservations in Mexico during the period of outbreak, and many countries, mainly Argentina and Cuba, have suspended their flights to and from Mexico.

\section{Acquired immune deficiency syndrome (AIDS)}

It is an infectious disease with human immunodeficiency virus (HIV) origin that cause for human immune system to collapse. HIV attacks immune system of the body, and by penetrating to CD4 (white blood cells), thus weakens the immune system. Acquired immune deficiency syndrome (AIDS) has caused for the death of more than 32 million people to date. AIDS has influenced tourism industry, having an important place in Southern African economy, to be negatively affected. In his study, Ketshabile (2013) has mentioned that the disease has caused for the economical growth in Southern African region to get reduced by the ratio of $25 \%$ in the period between 1980 and 2000s. In this same study, it is being stated that the biggest impact of AIDS on tourism was related with the loss of qualified labor force. The study of Strydom and Carolus (2010) also supports this outcome. In the relevant study, it is mentioned that AIDS has caused for a big unemployment problem to arise in Southern African region.

\section{Severe acute respiratory syndrome (SARS)}

Coronavirus originated severe acute respiratory syndrome (SARS) which has come out in China in November 2002 is a disease showing rapid spreading and high level of death incidents. This rapidly spreading disease has reached to 26 countries and has been transmitted to more than 8,000 people (Wilder-Smith et al., 2020). Although SARS has shorter period of survival as having less number of cases and incidents when compared with other diseases, it is known that it has caused negative economical impacts. In China, tourism has been one of the sectors being mostly affected from this outbreak. Beijing, Guangzhou and Shanghai, the three biggest cities of China, have been shown as the regions where economical impact of disease was observed the most. While SARS especially caused for travel cancelations in these cities and for low occupancy rates such as $1.6 \%$ in these cities, this outbreak caused for a loss worth of 2.8bn dollars in Chinese tourism sector (Breda, 2004).

Besides China, SARS outbreak also affected the economy and tourism negatively in different countries and regions. Siu and Wong (2004) have stated that in Hong Kong, total number of visitors reduced as per the ratio of $63 \%$ in March-April 2003. Pine and McKercher (2004) mentioned that in Singapore and Hong Kong, in the approximate period of four months during SARS pandemic, the share of tourism within gross national product reduced as per the ratios of $41-42 \%$. It is known that the loss in gross national product in Southeastern Asia in the year 2003 amounted to 18bn dollars (Bhati et al., 2016, p. 150). In his study titled "Getting prepared for the next pandemic" and dated 2005, Osterholm attracted attention in particular that even in case of a small pandemic, loss of lives would be tremendous and that its cost to the global economy would be high, and that this economical confusion period would continue for a couple of years. Dwyer et al. (2006) indicated that the outbreak has caused for hotel and travel cancelations in Australia, and that it has negatively affected the tourism activities in Australia. In their study which Jayawardena et al. (2008) prepared to provide strategical hints for destination and hotel managers by determining the impact of SARS outbreak on tourism 
sector, they have emphasized that there was a need for an integrated plan with regards to this type of crisis that could come out. It is mentioned that due to SARS the total loss in tourism revenues incurred in Toronto between months of March and July was worth 342.5m dollars, and that major part of this loss originated from accommodation. In the week of April 27,2003, when the sharpest fall was observed, it was predicted that the hotels in Toronto incurred a revenue loss with the rate of $75 \%$ when compared with the same period in 2002 . With respect to employment, it is known that 12,100 people, who were employed mainly in accommodation and food and beverages sector in Toronto tourism industry, lost their jobs and working hours of some of the workers were reduced (Jayawardena et al., 2008, p. 335).

Tufts (2009) has examined Hospitality Workers Resource Centre (HWRC) which has been established as a model for hotel management unions by the union named Local 75 in order to provide services for accommodation enterprises' employees, who have lost their jobs in Toronto following SARS outbreak. The center was opened in January 2004, nine months after the crisis has started, but it was closed in October 2004. According to HWRC records, 4,490 visits were realized by 1,022 people between January and August 2004. Employees in the accommodation sector were faced with long-term unemployment in the years of 2003-2004, their debts have accumulated and when they have returned to their work, they were mainly included in part-time working system, whereas they had to work for lower wages.

Chuo (2007, p. 91) has emphasized by considering the possibility of outbreak can reoccur, following the period after the SARS incident, it was required for managers in tourism industry to derive lessons about how they should protect their guests if such a situation would arise, and they had to develop survival strategies. Menon and Goh (2005, p. 382) mentioned that following SARS incident, the ministries in Singapore carried out important studies and that they have put in their efforts in order to resuscitate the country.

\section{Ebola}

It is a fatal disease which has first come out in the African continent, and which was discovered in 1976 in Democratic Republic of Congo. The disease gets its name from Ebola River in Congo. Ebola, is a disease that the impacts are continuing, has also spread to the continents of Asia, Europe and America, besides Africa. Because of the vaccine for the disease is developed, its spreading has been taken under control (Anis, 2019; CDC, 2020a). Ebola has influenced economies and tourism activities of countries in African continent and mainly those in Western Africa, negatively. Although the outbreak was observed in Western Africa, a perception was raised as if it was spread to whole African continent (Maphanga and Henama, 2019). Liberia, Sierra Leone and Guinea were the most economically affected countries by the outbreak. The outbreak has caused a contraction in economical growth of these countries. Besides, due to the outbreak, the World Health Organization (WHO) has recommended cancellation of flights to African countries and leading global airline companies have canceled their flights by complying with this recommendation. This situation has negatively affected tourism, having an important share among total revenues (Sifolo and Sifolo, 2015). Anis (2019) stated that Nigeria was among the countries being most impacted by the Ebola outbreak in the tourism industry. In the relevant study, it has been stated that in April 2004 the hotels in Nigeria were faced with reservation losses as per the rate of $75 \%$, and Ebola caused a loss of 8 bn Naira (nearly US $\$ 21 \mathrm{~m}$ ) in the Nigerian economy.

\section{Middle East respiratory syndrome (MERS)}

Middle East respiratory syndrome (MERS) is a coronavirus originating respiratory track disease which has first come out in Saudi Arabia in 2012. MERS, which showed a lower spreading when compared with other pandemic diseases, has caused for 858 death incidents being approved as of the year 2019 , whereas 780 out of these death incidents have occurred in
Impact of
COVID-19 on

the tourism industry 
IHR

36,1

Saudi Arabia (WHO, 2020b). The Saudi Arabian government has worked to ensure that the outbreak does not hamper the Hajj and Umrah organizations (BBC, 2014). The biggest reason for the spread of MERS disease outside of Arabia is expressed as people returning from Hajj and Umrah and transmitting the disease (Pavli et al., 2014). Besides the Arabian Peninsula, one of the countries being affected from the outbreak has been Korean Republic. MERS influenced accommodation, food and beverages, and transportation sectors negatively in Korean Republic. Joo et al. (2019), explained that MERS outbreak has caused for Korean Republic to incur loss of 2.1 million tourists, and the revenue loss of $2.6 \mathrm{bn}$ dollars.

\section{Coronavirus (COVID-19) and its impacts}

The coronavirus disease 2019 (COVID-19) epidemics known as a general health crisis that has caused challenges for mental resilience, and has been the biggest outbreak since the SARS outbreak in 2003 (Wang et al., 2020b). The epidemiological novelty of COVID-19 (the SARS-CoV2), which caused by a strain of coronavirus, revealed our lack of preparedness given its sudden and rapid spread that many governments around the world caught unprepared (Djalante et al., 2020). The epicenter of the disease was the city of Wuhan, particularly has a live animal market which was closed afterward. First called "severe acute respiratory syndrome coronavirus 2 (SARS-CoV-2)" due to its genetic similarity to SARS (the outbreak of which was seen in 2003), on February 11, 2020. Several clusters of patients with pneumonia of unknown cause were reported in late December 2019 in Wuhan, the capital city of Hubei province, China. It was later identified to be caused by a new coronavirus (severe acute respiratory syndrome coronavirus 2, or SARS-CoV-2) (Zhu et al., 2020) and the WHO (2020c) named it "Covid-19" (Ali, 2020). The WHO named the disease caused by the virus COVID-19, which refers the type of virus and the year it emerged. The WHO declared that the virus is a pandemic (Ali, 2020).

The constant spread of the pandemic, unfortunately, continues to negatively affect the areas of economic-social life, especially the health system of countries. Initial public health guidance for workers during the 2019-2020 COVID-19 pandemic was focused on ensuring workers stay home when sick, minimize nonessential travel and practice good hygiene in order to slow the transmission of disease between workers and community members (CDC, 2020b). As the number of cases continued to grow, and community transmission was apparent, subsequent guidance focused on encouraging all workers to work from home, with many workplaces adopting a work from home requirement (Frenkel, 2020; Weise, 2020). In many countries, schools were closed or provide fully online courses (Samuel and Walsh, 2020; Education Week Map, 2020), retail establishments closed or work with severely reduced hours, and bars and restaurants either closed or moved to a model of takeout and delivery only (Testa et al., 2020; Hussain et al., 2020). This public health guidance, while necessary for halting the spread of a global pandemic such as COVID-19, can have drastic effects on workers (CDC, 2020b).

The initial primary impact of COVID-19 is on the supply side. Factory closures in many countries and contraction in macroeconomic supply of goods and services, moving the global economy from point "a to point b" - lower output, higher prices or what is known as "stagflation". In order to understand the economic effects of this pandemic, it is necessary to take a look at the supply-demand situation. Assessing the macroeconomic impact of COVID-19, a good starting point is the observation by Deloitte 4 that "Covid-19" could affect the global economy in three main ways: by directly affecting production (supply), by creating supply chain and market disruption (supply) and by its financial impact on firms and markets (principally, demand) (Maital and Barzani, 2020).

Note that the second-round impact of a global epidemic will result in moderate to major contractions in demand. As supply-side disruptions close factories and places of work, 
consumers will cut back on their spending, shifting demand curves inward, reducing GDP, boosting unemployment and moderating price rises.

Tourism is susceptible to the effects of pandemics because it is based on the interaction among people (UNWTO 2020a). As a result, tourism is one sector that has borne a lot of the impact of COVID-19. The United Nations World Tourism Organization (UNWTO 2020a) mentions that the COVID-19 pandemic is a big challenge for the sector and requires reliable and impeccable leadership that will prioritize tourism during the recovery phase. Many countries are already enduring the negative consequences of the COVID-19 pandemic. For example, in Thailand, the collapse of the Chinese market has provoked a sharp drop in business as many flower sellers, drivers of the "red car" minibuses, traditional dancers and others have reported a reduction in their monthly income by half, while the informal association of tour guides in Thailand is of the view that 25,000 people have lost their jobs (Head, 2020). These are mostly small businesses that do not often have adequate funding to survive, but are vulnerable to the vicissitudes of the COVID-19 pandemic. In the USA, it is estimated that the city of Louisville alone lost an estimated $\$ 57.6 \mathrm{~m}$ because of cancellations occasioned by COVID-19. As such, there is a worry around the world about the sector's growth prospects in many countries worldwide (Coomes et al., 2020).

\section{Comparison of previous pandemics with COVID-19 in terms of effects on tourism economy}

Pandemic diseases are defined as events that cause high level of costs for individuals and communities, the outcomes of which cannot be predicted but which can repeat themselves. While pandemic diseases can come out in different forms, they can influence various different organs of the body. But respiratory track diseases have an important share among other epidemic diseases. It is known that with regards to this type of respiratory track diseases being frequently observed through the history, epidemics and pandemics have a destructive force that disrupts the community and economy severely and which cause severe level of costs on global scale. Especially their impacts on the health and services sector are immense (Moran and Del Valle, 2016, p. 2; Ponnambalam et al., 2016, p. 1). The pandemic causes very severe level of losses in relation to the performance of tourism sector in the country being impacted (Bhati et al., 2016, p. 150). For example in the study being conducted by Kim et al. (2020), the impact of epidemic diseases on the restaurant sector have been examined an it was revealed that the diseases influenced brand confidence, advertisement and service varieties in a negative way.

Outbreaks in the past, many of which are in the 2000s, are still in people's memory. Outbreaks like MERS and Ebola may not be remembered as very important since they are limited to the local spreading area. However, the risk of death of a person with MERS infection is higher than SARS and COVID-19. The link between these three viruses is probably all of them transmitted from animal to human. However, while SARS and COVID-19 can be easily transmitted from person to person, this feature of MERS is known to be more limited. Table 1 shows the location of pandemic and epidemic diseases, date of occurrence, number of infections and deaths. This table provides a general pandemic assessment. It is observed that there is no continuity of diseases as a result of mutation or recovery (except COVID-19 as of May 5,2020). From the 21st century, an increase in the detection or emergence of diseases has been observed.

The effects of previous pandemics and COVID-19 on the economy, especially unemployment, are presented in Tables 2 and 3. As can be seen from the table, the unemployment rate increased during the flu epidemic in 2009 (it should be noted that it will have an impact on the financial crisis in 2009). It cannot be said that there was a serious increase in unemployment rates in other pandemic periods (except COVID-19).
Impact of

COVID-19 on

the tourism industry 
IHR
36,1

\begin{tabular}{|c|c|c|c|c|}
\hline Pandemic & Location & Date & Number of infections & Death count \\
\hline Flu pandemic & Worldwide & 1889-1999 & - & 1 million \\
\hline Spanish flu & Worldwide & $\begin{array}{l}1919 \\
1920\end{array}$ & About 500 million & 50-70 million \\
\hline Asian flu & Worldwide & $\begin{array}{l}1957 \\
1958\end{array}$ & - & $1.5-2$ million \\
\hline Hong Kong flu & Worldwide & $\begin{array}{l}1968 \\
1969\end{array}$ & - & 1 million \\
\hline SARS I & Asia-Canada & $\begin{array}{l}2002 \\
2003\end{array}$ & 8.455 & 790 \\
\hline 2009 flu pandemic & Worldwide & 2009 & 630 thousand & $14.286+$ \\
\hline SARS & Worldwide & 2012 & - & 449 \\
\hline MERS & Worldwide & 2012 & 2.494 & 858 \\
\hline Ebola virus I & West Africa & $\begin{array}{l}2013 \\
2016\end{array}$ & - & 2.279 \\
\hline Swine flu & Indian & $\begin{array}{l}2015 \\
2019\end{array}$ & 9.029 & 2.035 \\
\hline Ebola virus II & Democratic Republic of Congo & 2018 & 3.461 & 2.279 \\
\hline COVID-19 & Worldwide & 2019 & $\begin{array}{l}\text { COVID-19 figures are } \\
\text { as of month-date-year }\end{array}$ & till increasing \\
\hline
\end{tabular}

Table 1.

Information on pandemic diseases

Source(s): Turkish Thoracic Society, 2011; Short et al., 2018; WHO, 2018, 2019, 2020b, d, e; T.C. Ministry of Health, 2009, 2019; Sino Biological, 2020

Unemployment rates for COVID-19 cannot be given in Table 2, because the pandemic continues and unemployment rates are not disclosed by governments.

However, the report prepared by the International Monetary Fund (IMF) (April 2020) states that there will be sharp declines in the economy in 2020, and consequently increases in unemployment rates and the number of businesses closed. As a result of the COVID-19 pandemic, Lock (2020) estimates that the global travel and tourism market will result in 100.8 million job losses worldwide in 2020. The regions that are expected to suffer the most are the Asia-Pacific (63.4 million) and European (13 million) countries, respectively.

Table 2.

Economic impact of pre-COVID-19 pandemics

\begin{tabular}{lcccc}
\hline SARS I - unemployment rate & 2001 & 2002 & 2003 & 2004 \\
\hline Canada & 7.22 & 7.67 & 7.58 & 7.16 \\
OECD & 6.33 & 6.90 & 7.08 & 6.95 \\
\hline 2009 flu pandemic - unemployment rate & 2007 & 2008 & 2009 & 2010 \\
\hline Mexico & 3.65 & 3.90 & 5.38 & 5.33 \\
Canada & 6.03 & 6.15 & 8.35 & 8.02 \\
OECD & 5.63 & 5.96 & 8.16 & 8.35 \\
\hline SARS II - MERS - Unemployment rate & 2011 & 2012 & 2013 & 2014 \\
\hline OECD & 7.98 & 7.97 & 7.92 & 7.36 \\
\hline Ebola virus I - Unemployment rate & 2012 & 2013 & 2014 & 2015 \\
\hline West Africa & 24.87 & 24.73 & 25.07 & 25.34 \\
Source(s): IMF, 2020; OECD, 2020 & & & & \\
\hline
\end{tabular}




\begin{tabular}{|c|c|c|c|c|c|}
\hline COVID-19 growth forecast & Real GDP (million \$) & 2019 & 2020 & 2021 & Impact \\
\hline USA & 20.580 .250 & 1.7 & -6.1 & 4.7 & the tourism \\
\hline Spain & 1.427 .533 & 2.0 & -8.0 & 4.3 & IIIC LUIST \\
\hline Italy & 2.075 .856 & 0.3 & -9.1 & 4.8 & industr \\
\hline France & 2.780 .152 & 1.3 & -7.2 & 4.5 & \\
\hline UK & 2.828 .833 & 1.4 & -6.5 & 4.0 & \\
\hline Germany & 3.951 .340 & 0.6 & -7.0 & 5.2 & 73 \\
\hline Turkey & 771.274 & 0.9 & -4.6 & 4.5 & \\
\hline Russia & 1.657 .250 & 1.3 & -5.5 & 3.5 & \\
\hline China & 13.368 .073 & 6.1 & 1.2 & 9.2 & \\
\hline World output & - & 2.9 & -3.0 & 5.8 & Economic impact \\
\hline \multicolumn{5}{|c|}{ Source(s): IMF, 2020; OECD, 2020} & COVID-19 pandem \\
\hline
\end{tabular}

In this research, especially the relations between pandemics and tourism economy are emphasized. Especially tourist arrival, destination selection, expenditure, etc. topics attracted the attention of researchers (Kuo et al., 2008; McAleer et al., 2010; Cooper, 2006; Zeng et al., 2005; Blake et al., 2003; Rossello et al., 2017; Dinarto et al., 2020; UNWTO, 2020b). Cooper (2006) points out that the number of tourists will increase rapidly when the current threat is reduced, in his study of Japanese tourism and the SARS outbreak. Kuo et al. (2008), in their study on SARS and Avian influenza, they found that Asian tourism demand was heavily damaged by SARS rather than Avian influenza. However, it is stated that if this flu type develops in a way that it can be passed from person to person, bird flu may be a potential threat to international tourism. Rossello et al. (2017) emphasize that if this outbreak is eliminated in countries affected by Ebola, there will be an increase of five million in international tourists and 375 million in tourism revenues. Another study states that the Indonesian tourism industry suffered around $\$ 500 \mathrm{~m}$ per month due to the COVID-19 outbreak (Dinarto et al., 2020). UNWTO (2020b) estimates a \$300-450bn decrease in international tourism revenues for 2020. In addition, it is stated that the arrival of international tourists decreased by $4 \%$ due to the global economic crisis in 2009 and this rate was around $0.4 \%$ in the SARS outbreak in 2003. As a result, direct and indirect unemployment in the tourism industry is expected to increase in the near future (Koirala and Acharya, 2020). However, it is also argued that continuing adverse conditions can offer the tourism industry an opportunity to reorganize and restructure (Giampiccoli and Saayman 2016, p. 3; Mtapuri and Giampiccoli, 2020).

It is known that the risk of an infectious disease being observed in a destination constitute the most important reason why people change their travel plans (Kozak et al., 2007). For this reason, in cases of epidemics where tourism sector cannot develop a standard measure and remain defenseless, industrial and corporate disaster management studies should be done as based on duration, control level, degree of harm being caused and the number of people being affected (Bhati et al., 2016, p. 149). This particular is also closely related with awareness situations and measures of employees in relation to this type of epidemics. Tourism industry is very quickly influenced from pandemic diseases and travel advices, and restrictions are brought up by the government officers. This situation causes for decreases in both domestic and international travels and as an outcome of this, the demand for accommodation sector is negatively affected from this situation (Bharwani and Mathews, 2012, p. 421). Travel and accommodation sectors attract attention as being the sectors that incur losses first in case of an epidemic (Menon and Goh, 2005, p. 376). When it is considered from this aspect, it can be stated that applications with awareness and precaution purposes against the disease could mitigate such losses or that they could relatively avoid them. 
IHR

36,1

During the epidemics periods, consumers do not wish to travel and demand for hotels decreases. This reduction causes for important financial losses throughout the world and gives rise to long-term negative impacts. In this regard, the study carried out by Zemke et al. (2015) about what level of charges could be acceptable to be paid if disinfection processes are applied in hotel cleaning and especially in the rooms together with advanced cleaning methods attracts attention. As a result of the study, it has come out that youngsters and women could pay for higher charges in the hotels where disinfection processes were applied. Especially during epidemic periods and afterward, this type of applications could contribute to increase mobility in the tourism industry.

In their study, Jamal and Budke (2020) have evaluated tourism in a world where there is a pandemic, with respect to local and global responsibility. It is emphasized that governments and the stakeholders in tourism industry should consider the costs, risks and impacts of global environmental hazards on traveling and tourism even more. In the study, two major drivers of change experienced in tourism in 21st century are climate change and global emergency health cases, and COVID-19 is given as an example for global emergency health cases. Many countries publish the measures required to be taken by the open tourism enterprises during the period of COVID-19 outbreak.

Ozatay and Sak (2020), attract attention to the tourism enterprises that shutdown with the application of social distance measure within the scope of COVID-19, and they emphasize that the enterprises should not reduce their employee numbers by getting government support. They mention that this global outbreak will cause a deep economical contraction, and that there will be a decrease in gross national product. It is stated that against a global event two types of attitudes could be demonstrated, whereas the first one of these would be considering the event to be similar to an earthquake and to take action after it is finished. Other type of attitude would be developing measures that could keep all enterprises open against the situation, the ending of which cannot be definite.

\section{Discussion}

The epidemic diseases that started with the 1900s have created social, cultural and economic effects as well as health problems and deaths. While the outbreaks had created their effects within the time they occurred, these effects - especially in the economy - continued after the outbreak had completely ended. The main epidemics that have had a significant impact on the tourism industry are Ebola, SARS and COVID-19. The economic effects of flu outbreaks remained lower than Ebola, SARS and COVID-19. Flu outbreaks have shown their effects mostly on social life (Ammon, 2002). Among the flu outbreaks, swine flu was the disease that most affected the economy and tourism activities. While the disease primarily affected the agriculture and transportation sector, it caused the cancellation of holiday and airline reservations in Mexico and the USA (McKibbin, 2009).

Although Ebola, and SARS outbreaks caused economic losses, they did not cause high fluctuations in unemployment rates. In the Ebola epidemic, the unemployment rate in West African countries was around $24-25 \%$. In the SARS epidemic process, the unemployment rate of the countries affected by the epidemic varied between 6 and $7 \%$. In 2009, when the swine flu epidemic occurred, the unemployment rate in Mexico, Canada and organisation for economic co-operation and development (OECD) countries increased compared to previous years. But it is not correct to say that the main reason for this increase is the epidemic. The global economic crisis in 2008 is the main reason for the increase in unemployment rates (OECD, 2020).

All outbreaks in the past have caused economic problems along with health (Yeganeh, 2019). While the fight against outbreaks is an important cost, the fact that industrial 
production has come to a halt worldwide causes significant economic losses. COVID-19, which appeared in the world in December 2019, was declared as a pandemic by the WHO in a very short time due to its high transmission rate. For this reason, governments around the world have started to take many measures especially since February 2020. Social isolation comes first among the measures taken. To ensure social isolation, many workplaces have been closed and travel has been restricted (Ferguson et al., 2006). Today, all sectors and industrial organizations in the countries continue to experience the negative economic effects of the outbreak strongly. Pandemic also continues to adversely affect the labor market, education system and sociocultural life (Koirala and Acharya, 2020).

With the rapid spread of COVID-19 from China to the world, both other countries and various organizations have begun to disclose measure packages. In addition to general information, the WHO has published a guide for the measures that tourism businesses should take during the COVID-19 epidemic process. The most important factor that comes to the fore in the guide is to arrange both the personnel and the guest environment according to the social distance rules (WHO, 2020a). This will lead businesses to host fewer guests and thus employ fewer staff members. In this period, both businesses and employees are expected to suffer a significant loss of income.

Similar results were obtained in the studies examining the social and psychological effects of pandemics that occurred in previous years. For example, Blake et al. (2010) report that epidemic diseases cause anxiety in employees and this anxiety causes job insecurity. Another reason for job insecurity in individuals is that the pandemic is described as "serious". Savaş and Tanriverdi (2010) stated that, $60.3 \%$ of the participants of their study related to the swine flu, which disease also seen in Turkey, said that they have considered a serious epidemic. However, since the population of this research is composed of healthcare professionals, the level of awareness of the disease is assumed to be at this level. The COVID-19 outbreak has been brought under control in many countries as of May 2020. The spread of the disease has begun to slow down outside of the USA, Russia and Brazil (WHO, 2020e). Controlling the epidemic allowed countries to enter the normalization process. Within the scope of normalization, the measures taken in the first months of the epidemic are removed in a controlled manner.

Although the number of cases and the rate of increase decreased in the second quarter of 2020 , the number increased again in the third quarter. The continuation of the outbreak will cause the measures taken for tourism enterprises to continue. Continuation of prohibitions for international flights and intercity travel will cause to lose income and employment in the tourism industry.

\section{Conclusion}

The public, who referred to the pandemics in the past, probably had an optimistic viewpoint on the effects of COVID-19. But the whole world has suffered greatly in all areas, and seems to continue to suffer for a while. Undoubtedly, as in all areas, historical data are a reference in pandemics. However, COVID-19 was a heavy and violent lesson. The world, which has not experienced such the loss of life and economic devastation for a long time, has begun to believe that everything should be reconstructed. Unlike other pandemics, COVID-19 becomes a new type of virus, with its rapid spread all over the world, creating more than 1.92 million (January 2021) casualties and upsetting the economy. Of course, this pandemic will end someday. However, the losses it creates will continue to affect the whole world for a long time.

On the other hand, uncertainties regarding pandemic continue to cause anxiety in people and economies. Due to this anxiety, both the health and economy will continue to have difficulties in returning to the past. Although COVID-19 is relatively controlled, the measures are expected to continue all over the world. This means that problems will continue in all
Impact of
COVID-19 on

the tourism industry 
IHR

36,1

areas. When this study is prepared, the effects of the pandemic was decreasing but continuing. A well-known fact is that COVID-19 is very different from others and that new future outbreaks should also be addressed with this reference.

\section{References}

Acar, Y. (2020), "Yeni Koronavirüs (COVID-19) salgını ve turizm faaliyetlerine etkisi”, Güncel Turizm Araştırmalan Dergisi, Vol. 4 No. 1, pp. 7-21, doi: 10.32572/guntad.703410.

Ahmed, F., Ahmed, N., Pissarides, C. and Stiglitz, J. (2020), "Why inequality could spread COVID-19", Lancet Public Health, Vol. 5 No. 5, doi: 10.1016/S2468-2667(20)30085-2.

Ali, I. (2020), "The COVID-19 pandemic: making sense of rumor and fear", Medical Anthropology Cross-Cultural Studies in Health and Ilness, Vol. 26 Mar 2020, pp. 1-4, doi: 10.1080/01459740. 2020.1745481.

Ammon, C.E. (2002), "Spanish flu epidemic in 1918 in Geneva, Switzerland", European Communicable Disease Bulletin, Vol. 7 No. 12, pp. 190-192, doi: 10.2807/esm.07.12.00391-en.

Anis, O. (2019), "Western african Ebola virus edidemic”, WikiJournal of Medicine, Vol. 6 No. 1, pp. 1-34, doi: $10.15347 / \mathrm{wjm} / 001$.

Avcikurt, C., Koroglu, O., Koroglu, A. and Solmaz Avcikurt, A. (2011), "HIV/AIDS awareness and attitudes of tour guides in Turkey", Culture, Health and Sexuality, Vol. 13 No. 2, pp. 233-243, doi: 10.1080/13691058.2010.522733.

BBC (2014), "MERS: Saudis in push to keep Hajj free from deadly virus", available at: https://www. bbc.com/news/world-middle-east-29147727 (accessed 14 April 2020).

Bharwani, S. and Mathews, D. (2012), "Risk identification and analysis in the hospitality industry: practitioners' perspectives from India", Worldwide Hospitality and Tourism Themes, Vol. 4 No. 5, pp. 410-427, doi: 10.1108/17554211211277851.

Bhati, A., Upadhayaya, A. and Sharma, A. (2016), "National disaster management in the ASEAN-5: an analysis of tourism resilience", Tourism Review, Vol. 71 No. 2, pp. 148-164, doi: 10.1108/TR-122015-0062.

Blake, A., Sinclair, M.T. and Sugiyarto, G. (2003), "Quantifying the impact of foot and mouth disease on tourism and the UK economy", Tourism Economics, Vol. 9, pp. 449-465, doi: 10.5367/ 000000003322663221.

Blake, K.D., Blendon, R.J. and Viswanath, K. (2010), "Employment and compliance with pandemic influenza mitigation recommendations”, Emerging Infectious Diseases, Vol. 16 No. 2, pp. 212-218, doi: 10.3201/eid1602.090638.

Breda, Z. (2004), "The impact of severe acute respiratory syndrome (SARS) on China's tourism sector", Tourism Research Journal, Vol. 1 No. 2, pp. 5-14.

Cahyanto, I., Wiblishauser, M., Pennington-Gray, L. and Schroeder, A. (2016), "The dynamics of travel avoidance: the case of Ebola in the US”, Tourism Management Perspectives, Vol. 20, pp. 195-203, doi: 10.1016/j.tmp.2016.09.004.

CDC (2020a), "Ebola (Ebola virus disease)", available at: https:/www.cdc.gov/vhf/ebola/index.html (accessed 14 April 2020).

CDC (2020b), "Guidance for businesses and employers to plan and respond to coronavirus disease 2019 (COVID-19)", available at: https:/www.cdc.gov/coronavirus/2019 ncov/specific-groups/ guidance-business-response.html (accessed 26 February 2020).

Chuo, H.Y. (2007), "Theme park visitors' responses to the SARS outbreak in Taiwan", Advances in Hospitality and Leisure, Vol. 3, pp. 87-104, doi: 10.1016/S1745-3542(06)03006-2.

Coomes, S., Huston, K. and Mangeot, M. (2020), "The future of bourbon tourism", The Rebirth of Bourbon: Building a Tourism Economy in Small-Town, USA (Economics of Vice), Emerald Publishing Limited, pp. 113-137. 
Cooper, M. (2006), "Japanese tourism and the SARS epidemic of 2003", Journal of Travel and Tourism Marketing, Vol. 19, pp. 117-131, doi: 10.1300/J073v19n02_10.

de Francisco, N., Donadel, M., Jit, M. and Hutubessy, R. (2015), "A systematic review of the social and economic burden of influenza in low-and middle-income countries", Vaccine, Vol. 33 No. 48, pp. 6537-6544, doi: 10.1016/j.vaccine.2015.10.066.

Dinarto, D., Wanto, A. and Sebastian, L.C. (2020), "Global health security-COVID-19: impact on Bintan's tourism sector”, RSIS Commentaries, pp. 1-3.

Djalante, R., LassaSetiamarga, J.D., Mahfud, C., Sudjatma, A., Indrawan, M., Haryanto, B., Sinapoy, M.S., Rafliana, I., Djalante, S., Gunawan, L.A., Anindito, R., Warsilah, H. and Surtiari, I.G.A. (2020), "Review and analysis of current responses to COVID-19 in Indonesia: period of January to March 2020”, Progress in Disaster Science, April 2020, pp. 1-9, doi: 10.1016/j.pdisas.2020. 100091.

Dwyer, L., Forsyth, P. and Spurr, R. (2006), "Effects of the SARS crisis on the economic contribution of tourism to Australia", Tourism Review International, Vol. 10 Nos 1-2, pp. 47-55, doi: 10.3727/ 154427206779307231.

Education Week Map (2020), "Coronavirus and school closures", available at: https:/www.edweek. org/ew/section/multimedia/map-coronavirus-and-school-closures.html\# (accessed 20 March 2020).

El-Sayyed, N., Kabbash, I.A. and El-Gueniedy, M. (2008), "Knowledge, attitude and practices of Egyptian industrial and tourist workers towards HIV/AIDS", La Revue de Sante de la Mediterranee Orientale, Vol. 14 No. 5, pp. 1126-1135.

Ferguson, N.M., Cummings, D.A., Fraser, C., Cajka, J.C., Cooley, P.C. and Burke, D.S. (2006), "Strategies for mitigating an influenza pandemic", Nature, Vol. 442 No. 7101, pp. 448-452, doi: 10.1038/ nature04795.

Frenkel, S. (2020), "The week in tech: welcome to the age of mandatory videoconferencing", New York Times, available at: https://www.nytimes.com/2020/03/06/technology/coronavirus-techbusinesses.html (accessed 6 March 2020).

Garg, A. (2013), "A study of tourist perception towards travel risk factors in tourist decision making", Asian Journal of Tourism and Hospitality Research, Vol. 7 No. 1, pp. 47-57.

Garrett, T.A. (2007), "Economic effects of the 1918 influenza pandemic", available at: https://www. stlouisfed.org/ /media/files/pdfs/community-development/research-reports/pandemic_flu_ report.pdf (accessed 13 April 2020).

Giampiccoli, A. and Saayman, M. (2016), "Community-based tourism: from a local to a global push", Acta Commercii, Vol. 16, pp. 1-10, doi: 10.4102/ac.v16i1.372.

Gilliland, S.E. (1990), "Health and nutritional benefits from lactic acid bacteria", FEMS Microbiology Letters, Vol. 87 Nos 1-2, pp. 175-188, doi: 10.1111/j.1574-6968.1990.tb04887.x.

Haque, T.H. and Haque, M.O. (2018), "The swine flu and its impacts on tourism in Brunei”, Tourism Management, Vol. 36, pp. 92-101, doi: 10.1016/j.jhtm.2016.12.003.

Head, J. (2020), “Coronavirus: tourism in Thailand hit by covid-19", BBC News, available at: https:// www.bbc.com/news/business-51796812 (accessed 16 March 2020).

Henderson, J.C. and Linh, T.H. (2007), "Tourist destinations and disease: vietnam's tourism industry and the SARS crisis", ASEAN Journal on Hospitality and Tourism, Vol. 6 No. 1, pp. 1-11.

Hoque, A., Shikha, F.A., Hasanat, M.W., Arif, I. and Abdul Hamid, A.B. (2020), "The effect of Coronavirus (COVID-19) in the tourism industry in China", Asian Journal of Multidisciplinary Studies, Vol. 3 No. 1, pp. 52-58.

Hussain, S., Chang, A. and Harris, J.L.A. (2020), "Bars forced to close, restaurants go takeout-only: "Some of these closures might be permanent", Los Angeles Time, available at: https:/www. latimes.com/business/story/2020-03-15/coronavirus-close (accessed 16 March 2020). 
IHR

36,1

IMF (2020), "World economic outlook", available at: https://www.imf.org/en/Publications/WEO/Issues/ 2020/04/14/weo-april-2020 (accessed 3 May 2020).

Jamal, T. and Budke, C. (2020), "Tourism in a world with pandemics: local-global responsibility and action", Journal of Tourism Futures, pp. 181-188, doi: 10.1108/JTF-02-2020-0014.

Jayawardena, C., Johnson Tew, P., Lu, Z., Tolomiczenko, G. and Gellatly, J. (2008), "SARS: lessons in strategic planning for hoteliers and destination marketers", International Journal of Contemporary Hospitality Management, Vol. 20 No. 3, pp. 332-346, doi: 10.1108/ 09596110810866145.

Joo, H., Maskery, B.A., Berro, A.D., Rotz, L.D., Lee, Y.K. and Brown, C.M. (2019), "Economic impact of the 2015 MERS outbreak on the Republic of Korea's tourism-related industries", Health Security, Vol. 17 No. 2, pp. 100-108, doi: 10.1089/hs.2018.0115.

Karlsson, M., Nilsson, T. and Picher, S. (2014), "The impact of the 1918 Spanish Flu epidemic on economic performance in Sweden an investigation into the consequences of an extraordinary mortality shock", Journal of Health Economics, Vol. 36, pp. 1-19, doi: 10.1016/j.jhealeco.2014. 03.005

Keogh-Brown, M.R. (2014), "Macroeconomic effect of infectious disease outbreaks", Encyclopedia of Health Economics, Vol. 2, pp. 177-180, doi: 10.1016/B978-0-12-375678-7.00608-8.

Keogh-Brown, M.R. and Smith, R.D. (2008), "The economic impact of SARS: how does the reality match the predictions?”, Health Policy, Vol. 88 No. 1, pp. 110-120, doi: 10.1016/j.healthpol.2008. 03.003 .

Ketshabile, L.S. (2013), "The implications of HIV/AIDS on tourism enterprises in the Sub-Saharan Africa”, Asian Journal of Empirical Research, Vol. 3 No. 7, pp. 836-850.

Kim, S.S., Chun, H. and Lee, H. (2005), "The effects of SARS on the Korean hotel industry and measures to overcome the crisis: a case study of six Korean Five-Star hotels", Asia Pacific Journal of Tourism Research, Vol. 10 No. 4, pp. 369-377, doi: 10.1080/10941660500363694.

Kim, J., Kim, J., Leec, S.K. and Tang, L. (2020), "Effects of epidemic disease outbreaks on financial performance of restaurants: event study method approach", Journal of Hospitality and Tourism Management, Vol. 43, pp. 32-41, doi: 10.1016/j.jhtm.2020.01.015.

Koirala, J. and Acharya, S. (2020), "Impact of novel corona virus (COVID-19 or 2019-nCoV) on Nepalese economy (March 24, 2020)", available at: https://ssrn.com/abstract=3560638 (accessed 20 April 2020).

Kozak, M., Crotts, J.C. and Law, R. (2007), "The impact of the perception of risk on international travellers", International Journal of Tourism Research, Vol. 9 No. 4, pp. 233-242, doi: 10.1002/ jtr.607.

Kuo, H.I., Chen, C.C., Tseng, W.C., Ju, L.F. and Huang, B.W. (2008), "Assessing impacts of SARS and Avian Flu on international tourism demand to Asia", Tourism Management, Vol. 29 No. 5, pp. 917-928, doi: 10.1016/j.tourman.2007.10.006.

Lee, C.C. and Chen, C.J. (2011), "The reaction of elderly Asian tourists to avian influenza and SARS", Tourism Management, Vol. 32 No. 6, pp. 1421-1422, doi: 10.1016/j.tourman.2010.12.009.

Lee, G.O. and Warner, M. (2006), "Human resources, labour markets and unemployment: the impact of the SARS epidemic on the service sector in Singapore", Asia Pacific Business Review, Vol. 12 No. 4, pp. 507-527, doi: 10.1080/13602380600571443.

Lock, S. (2020), "COVID-19: forecast job loss in travel and tourism sector worldwide 2020", available at: https://www.statista.com/statistics/1104835/coronavirus-travel-tourism-employment-loss (accessed 11 May 2020).

Luo, L. and Tan, X.D. (2005), "A survey on the knowledge, attitude, belief and practice related to AIDS among hotel attendants in Yichang city", Zhejiang Journal of Preventive Medicine, Vol. 17, pp. 11-13.

Maital, S. and Barzani, E. (2020), “The global economic impact of COVID-19: a summary of research", Samuel Neaman Institute for National Policy Research, pp. 1-10. 
Maphanga, P.M. and Henama, U.S. (2019), "The tourism impact of Ebola in Africa: lessons on crisis management", African Journal of Hospitality, Tourism and Leisure, Vol. 8 No. 3, pp. 1-13.

McAleer, M., Huang, B.W., Kuo, H.I., Chen, C.C. and Chang, C.L. (2010), "An econometric analysis of SARS and Avian Flu on international tourist arrivals to Asia", Environmental Modelling and Software, Vol. 25 No. 1, pp. 100-106, doi: 10.1016/j.envsoft.2009.07.015.

McKercher, B. (2003), "SIP (SARS induced panic) a greater threat to tourism than SARS (severe acute respiratory syndrome)", E-revise of Tourism Research (ERTR), Vol. 1 No. 1, pp. 17-18.

McKibbin, W.J. (2009), "The swine flu outbreak and its global economic impact", available at: https:// www.brookings.edu/on-the-record/the-swine-flu-outbreak-and-its-global-economic-impact (accessed 14 May 2020).

Menon, K.U. and Goh, K.T. (2005), "Transparency and trust: risk communications and the Singapore experience in managing SARS", Journal of Communication Management, Vol. 9 No. 4, pp. 375-383.

Mills, C.E., Robins, J.M. and Lipsitch, M. (2004), "Transmissibility of 1918 pandemic influenza", Nature, Vol. 432 No. 7019, pp. 904-906.

Min, J.C., Lim, C. and Kung, H.H. (2011), "Intervention analysis of SARS on Japanese tourism demand for Taiwan”, Quality and Quantity, Vol. 45 No. 1, pp. 91-102, doi: 10.1007/s11135-010-9338-4.

Moran, K.R. and Del Valle, S.Y. (2016), "A meta-analysis of the association between gender and protective behaviors in response to respiratory epidemics and pandemics", PloS One, Vol. 11 No. 10, doi: 10.1371/journal.pone.0164541.

Mtapuri, O. and Giampiccoli, A. (2020), "Toward a model of just tourism: a proposal”, Social Sciences, Vol. 9 No. 4, pp. 1-19, doi: 10.3390/socsci9040034.

Nigmatulina, K.R. and Larson, R.C. (2009), "Living with influenza: impacts of government imposed and voluntarily selected interventions", European Journal of Operational Research, Vol. 195 No. 2, pp. 613-627, doi: 10.1016/j.ejor.2008.02.016.

Nikiforuk, A. (2018), Mahşerin Dördüncü Athsı Salgın Ve Bulaşıcı Hastahklar Tarihi, İletişim Yayınları, Istanbul, TR.

OECD (2020), "Unemployment rate", available at: https://data.oecd.org/unemp/unemployment-rateforecast.htm\#indicator-chart (accessed 3 May 2020).

Osterholm, M.T. (2005), "Preparing for the next pandemic”, New England Journal of Medicine, Vol. 352 No. 18 , pp. 1839-1842.

Özatay, F. and Sak, G. (2020), “COVID-19'un ekonomik sonuçlarını yönetebilmek için ne yapılabilir?”, Tepav, Politika Notu, pp. 1-8.

Page, S., Yeoman, I., Connell, J. and Walker, L. (2006), "A case study of best practice-visit Scotland's prepared response to an influenza pandemic", Tourism Management, Vol. 27, pp. 361-393, doi: 10.1016/j.tourman.2006.01.001.

Page, S., Songi, H. and Wu, D.C. (2011), "Assessing the impacts of the global economic crisis and Swine Flu on inbound tourism demand in the United Kingdom", Journal of Travel Research, Vol. 51 No. 2, pp. 142-153, doi: 10.1177/0047287511400754.

Pavli, A., Tsiodras, S. and Maltezou, H.C. (2014), "Middle East respiratory syndrome coronavirus (MERS-CoV): prevention in travellers", Travel Medicine and Infectious Disease, Vol. 12, pp. 602-608, doi: 10.1016/j.tmaid.2014.10.006.

Pine, R. and McKercher, B. (2004), "The impact of SARS on Hong Kong's tourism industry", International Journal of Contemporary Hospitality Management, Vol. 16 No. 2, pp. 139-143, doi: 10.1108/09596110410520034.

Ponnambalam, L., Xiuju, F., Goh, R.S.M. and Sarawgi, D. (2016), “A multi-agent model for adaptive vaccination during infectious disease outbreaks", 2016 International Conference on Computing Technologies and Intelligent Data Engineering, ICCTIDE, Vol. 16, pp. 1-5.

Impact of
COVID-19 on

the tourism industry 
IHR

36,1

Porras-Gallo, M. and Davis, R.A. (2014), The Spanish Influenza Pandemic of 1918-1919: Perspectives from the Iberian Peninsula and the Americas, University of Rochester Press, New York, NY.

Rosenwald, M.S. (2020), "History's deadliest pandemics, from ancient Rome to modern America", available at: https://www.washingtonpost.com/graphics/2020/local/retropolis/coronavirusdeadliest-pandemics (accessed 7 April 2020).

Rosselló, J., Santana-Gallego, M. and Awan, W. (2017), "Infectious disease risk and international tourism demand", Health Policy and Planning, Vol. 32 No. 4, pp. 538-548, doi: 10.1093/heapol/ cZw177.

Samuel, H. and Walsh, J. (2020), "Growing number of European countries shut schools to curb spread of coronavirus", The Telegraph, available at: https:/www.telegraph.co.uk/news/2020/03/12/ ireland-closes-schools-colleges-uk-heads-delay-phase-coronavirus/ (accessed 12 March 2020).

Savaş, E. and Tanriverdi, D. (2010), "Knowledge, attitudes and anxiety towards influenza A/H1N1 vaccination of healthcare workers in Turkey", BMC Infectious Diseases, Vol. 10 No. 1, p. 281.

Short, K.R., Kedzierska, K. and van de Sandt, C.E. (2018), "Back to the future: lessons learned from the 1918 influenza pandemic", Frontiers in Cellular and Infection Microbiology, Vol. 8, p. 343, doi: 10. 3389/fcimb.2018.00343.

Sifolo, N. and Sifolo, P.P.S. (2015), "The tourism inconvenience of the Ebola epidemic: lessons for the South African tourism sector", African Journal of Hospitality, Tourism and Leisure, Vol. 4 No. 1, pp. 1-11.

Sino Biological (2020), available at: https://www.sinobiological.com/research/virus (accessed 3 May 2020).

Siu, A. and Wong, Y.C.R. (2004), "Economic impact of SARS: the case of Hong Kong", Asian Economic Papers, Vol. 3 No. 1, pp. 62-83, doi: 10.1162/1535351041747996.

Smith, R.D. (2006), "Responding to global infectious disease outbreaks: lessons from SARS on the role of risk perception, communication and management", Social Science and Medicine, Vol. 63 No. 12, pp. 3113-3123, doi: 10.1016/j.socscimed.2006.08.004.

Strydom, C. and Carolus, B.C. (2010), "Unemployment and HIV/AIDS in a rural community", Tiltai, Vol. 1, pp. 73-88.

T.C. Ministry of Health (2009), "H1N1 küresel grip salgını (pandemi)", available at: https://www.ttb. org.tr/h1n1/images/stories/sb/halk.pdf (accessed 3 May 2020).

T.C. Ministry of Health (2019), “Türkiye HIV/AIDS kontrol programı 2019-2024”, available at: https:// hsgm.saglik.gov.tr/depo/birimler/Bulasici-hastaliklar-db/hastaliklar/HIV-ADS/Tani-Tedavi_ Rehberi/HIV_AIDS_Kontrol_Programi.pdf (accessed 3 May 2020).

Testa, J., Maheshwari, S. and Friedman, V. (2020), "Which clothing and beauty stores have closed?", New York Times, available at: https://www.nytimes.com/ 2020/03/18/ style/coronavirusclothing-beauty-storesclosed.html (accessed 20 March 2020).

Tufts, S. (2009), "Hospitality unionism and labour market adjustment: toward Schumpeterian unionism?", Geoforum, Vol. 40 No. 6, pp. 980-990, doi: 10.1016/j.geoforum.2009.08.008.

Turkish Thoracic Society (2011), "SARS", available at: https://www.toraks.org.tr/news.aspx? detail $=902$ (accessed 3 May 2020).

UNWTO (2020a), “Tourism and coronavirus disease (COVID-19)", available at: https:/unwto.org/ tourism-covid-19-coronavirus (accessed 16 March 2020).

UNWTO (2020b), "COVID-19: UNWTO Calls on tourısm to be part of recovery plans", available at: https://www.unwto.org/news/international-tourism-arrivals-could-fall-in-2020 (accessed 2 May 2020).

Valette, M., Mosnier, A., Cohen, J.M. and Lina, B. (2004), "Impact of tourism on the epidemiology of influenza in the ski resorts of the French Alps", International Congress Series, Vol. 1263, pp. 376-380, doi: 10.1016/j.ics.2004.04.019. 
Wall, G. (2006), "Recovering from SARS: the case of Toronto tourism”, in Mansfeld, Y. and Pizam, A. (Eds), Tourism, Security and Safety: From Theory to Practice, Elsevier, pp. 143-152.

Wang, D., Zhou, M., Nie, X., Oiu, W., Yang, M., Wang, X., Xu, T., Ye, Z., Feng, X., Xiao, Y. and Chen, W. (2020a), "Epidemiological characteristics and transmission model of corona virus disease 2019 in China", Journal of Infection, pp. e25-e27, doi: 10.1016/j.jinf.2020.03.008.

Wang, C., Pan, R., Wan, X., Tan, Y., Xu, L., Ho, C.S. and Ho, R.C. (2020b), "Immediate psychological responses and associated factors during the initial stage of the 2019 coronavirus disease (COVID-19) epidemic among the general population in China", International Journal of Environmental Research and Public Health, Vol. 17 No. 5, pp. 1-25, doi: 10.3390/ijerph17051729.

Weise, K. (2020), "Ahead of the pack, how microsoft told workers to stay home", New York Times, available at: https://www.nytimes.com/2020/03/15/ technology /microsoft-coronavirus-response. html (accessed 15 March 2020).

WHO (2018), "HIV", available at: https://www.who.int/hiv/data/2018_summary-global-hiv-epi.png? ua $=1$ (accessed 3 May 2020).

WHO (2019), "MERS”, available at: http://applications.emro.who.int/docs/EMRPUB-CSR-241-2019-EN. pdf?ua $=1 \& u a=1 \& u a=1$ (accessed 3 May 2020).

WHO (2020a), "Food safety", available at: https://www.who.int/foodsafety/areas_work/zoonose/avian/ en/index1.html (accessed 6 April 2020).

WHO (2020b), "MERS”, available at: https:/www.who.int/emergencies/mers-cov/en/ (accessed 3 May 2020).

WHO (2020c), "WHO emergencies press conference on novel coronavirus", available at: https:/www. who.int/docs/default-source/coronaviruse/transcripts/who-audio-emergencies-coronaviruspress-conference-10feb2020-final.pdf?sfvrsn=680faf31_2 (accessed 26 February 2020).

WHO (2020d), "EBOLA", available at: https:/www.who.int/emergencies/diseases/ebola/drc-2019 (accessed 3 May 2020).

WHO (2020e), "WHO coronavirus disease (COVID-19) dashboard", available at: https://covid19.who. int/ (accessed 18 May 2020).

Wilder-Smith, A., Chiwe, C.J. and Lee, V.J. (2020), "Can we contain the COVID-19 outbreak with the same measures as for SARS?", The Lancet Infectious Diseases, pp. e102-e107, doi: 10.1016/ S1473-3099(20)30129-8.

Wu, E.H., Law, R. and Jiang, B. (2010), "The impact of infectious diseases on hotel occupancy rate based on independent component analysis", International Journal of Hospitality Management, Vol. 29 No. 4, pp. 751-753, doi: 10.1016/j.ijhm.2009.07.001.

Yang, Y., Zhang, H. and Chen, X. (2020), "Coronavirus pandemic and tourism: dynamic stochastic general equilibrium modeling of infectious disease outbreak", Annals of Tourism Research, pp. 1-6, doi: 10.1016/j.annals.2020.102913.

Yanni, E.A., Marano, N., Han, P., Edelson, P.J., Blumensaadt, S., Necker, M., Dwyer, S., Crocker, K., Daley, T., Davis, X., Gallagher, N., Balaban, V., Brown, C. and Kozarsky, P. (2010), "Knowledge, attitudes, and practices of US travellers to Asia regarding seasonal influenza and H5N1 avian influenza prevention measures”, Journal of Travel Medicine, Vol. 17 No. 6, pp. 374-381, doi: 10. 1111/j.1708-8305.2010.00458.x.

Yeganeh, H. (2019), "An analysis of emerging trends and transformations in global healthcare", International Journal of Health Governance, Vol. 24 No. 2, pp. 169-180, doi: 10.1108/IJHG-022019-0012.

Yeoman, I., Page, S., Connell, J., Walker, L. and Munro, C. (2006), “An influenza pandemic: what it could mean for Scottish tourism”, Quarterly Economic Commentary, Vol. 30 No. 4, pp. 47-54.

Zemke, D.M.V., Neal, J., Shoemaker, S. and Kirsch, K. (2015), "Hotel cleanliness: will guests pay for enhanced disinfection?", International Journal of Contemporary Hospitality Management, Vol. 27 No. 4, pp. 690-710, doi: 10.1108/IJCHM-01-2014-0020.
Impact of
COVID-19 on

the tourism industry 
IHR

36,1

Zhu, N., Zhang, D., Wang, W., Li, X., Yang, B., Song, J., Zhao, X., Huang, B., Shi, W., Lu, R., Niu, P., Zhan, F., Ma, X., Wang, D., Xu, W., Wu, G., Gao, G.F. and Tan, W. (2020), "A novel coronavirus from patients with pneumonia in China, 2019", New England Journal of Medicine, Vol. 382, pp. 727-733, doi: 10.1056/NEJMoa2001017.

\section{About the authors}

Gulcin Ozbay is an Assistant Professor of Food and Beverage Management Gastronomy and Culinary Arts at the Tourism Faculty at the Sakarya University of Applied Science. She holds PhD degree from Sakarya University (Turkey). She is a researcher on food and beverage management, food and beverage service, national and international gastronomy. Her publications have appeared in journals, such as Anatolia: A Journal of Tourism Research, International Journal of Management Economics and Business, Journal of Tourism and Gastronomy Studies. Her books are published by Detay Publishing Co., Turkey. Gulcin Ozbay is the corresponding author and can be contacted at: gozbay@subu.edu.tr

Mehmet Sariisik is a Professor of Food and Beverage Management Gastronomy and Culinary Arts at the Tourism Faculty at the Sakarya University of Applied Science. He holds $\mathrm{PhD}$ degree from Aydin Adnan Menderes University (Turkey). He is a researcher on food and beverage management, food and beverage service, food cost control, national and international gastronomy. His publications have appeared in journals, such as Asia Pacific Journal of Tourism Research, International Journal of Hospitality and Tourism Administration, African Journal of Business Management and Journal of Global Strategic Management. His books are published by Detay Publishing Co., Turkey.

Veli Ceylan is a research assistant in Food and Beverage Management Gastronomy and Culinary Arts at Sakarya University of Applied Sciences, Tourism Faculty. He is also a graduate student at Gazi University Department of Gastronomy and Culinary Arts. He is a researcher on gastronomy, food habits and food sociology.

Muzaffer Çakmak works as a Research Assistant at Istanbul Gelişim University, Department of Gastronomy (Turkey). He is a PhD Candidate student at Sakarya University of Applied Sciences, Faculty of Tourism, Tourism Management. He has publications in national and international areas. His research interests include gastronomy, food and beverage, tourism management.

For instructions on how to order reprints of this article, please visit our website:

www.emeraldgrouppublishing.com/licensing/reprints.htm

Or contact us for further details: permissions@emeraldinsight.com 